\title{
THE PRODUCTION OF BLOCK AND AURICULAR FIBRILLATION IN THE HEART-LUNG PREPARATION BY INHIBITORS OF CHOLINESTERASE
}

\author{
BY \\ J. H. BURN, E. M. VAUGHAN WILLIAMS, AND J. M. WALKER \\ From the Department of Pharmacology, University of Oxford \\ Received December 23, 1954
}

\begin{abstract}
As a result of the work of Otto Loewi it was discovered that the effects of vagal stimulation were transmitted to the heart by the release of acetylcholine. This substance itself when introduced into the circulation is known to have a powerful inhibitory action on both the rate and the force of the heart beat. Evidence has recently accumulated that, in addition to these inhibitory actions, acetylcholine has effects that may be regarded as excitatory. It is possible, indeed, that the inhibitory and excitatory effects of acetylcholine may be of significance in maintaining the normal rhythm of the heart. The evidence for this view is as follows. The heart contains not only acetylcholine itself, but the appropriate mechanisms for its synthesis by choline acetylase from choline (Comline, 1946), and for its destruction by cholinesterase (Ord and Thompson, 1950). It was found (Bülbring and Burn, 1949) that if rabbit auricles were allowed to beat in a bath of Ringer's solution until they stopped, the addition of acetylcholine caused the beat to start again. It was also found that choline acetylase activity was high in fresh rabbit auricles, but declined to a low value when the auricles were kept in a bath until they ceased to beat. When such non-beating auricles were restarted with acetylcholine it was found that their ability to synthesize acetylcholine had also been restored. These observations have led to further investigations of the part played by acetylcholine. The isolated rabbit heart perfused with Ringer's solution has been found to liberate acetylcholine in the perfusate so long as contractions continued, but if the beat was arrested, by perfusing either with $\mathrm{Ca}$-free Ringer, or by adding dinitrophenol to the perfusing fluid, acetylcholine was no longer liberated (Briscoe and Burn, 1954).

If acetylcholine plays a part in the maintenance of the normal rhythm, it is presumably destroyed by cholinesterase, and inhibitors of that enzyme should modify the rhythm. For a study of such an effect the Starling heart-lung preparation is suitable, since the heart is free from central control by the vagi and the sympathetic nerves. An account has already been published of the effect of cholinesterase inhibitors in reducing the rate of the beat in the heart-lung preparation of the dog (Burn and Walker, 1954). Concentrations of eserine, neostigmine, and other substances in the range $10^{-6} \mathrm{M}$ to $10^{-5} \mathrm{M}$ were found to lower the rate to about 60 to 70 per cent of its initial value, and the rate was rapidly restored by injections of small amounts of atropine.

We have now studied the effect of these inhibitors on the P-R interval and on the A-V block when the heart-lung preparation is driven electrically at increasing rates. We have also studied their effect on output at constant rate. Finally, we have studied the conditions in which they produce auricular fibrillation.
\end{abstract}

\section{METHODS}

The methods have been described recently (Burn et al., 1955a) and need only be summarized briefly. The heart-lung preparation of a dog was made (Knowlton and Starling, 1912). Heparin was used to prevent clotting. Electrodes were applied to the tip of the right auricle and held in position by a spring clip. 
The electrodes did not pierce the tissue and trauma was reduced to a minimum. Stimuli of $1 \mathrm{~mA}$ strength and $0.9 \mathrm{msec}$. duration were used. Leads to a Cossor electrocardiograph (model 1314) were taken from the right and left forelegs and left hindleg after removing a patch of skin. The inhibitors of cholinesterase (ChE) which were studied included eserine sulphate; neostigmine (prostigmin methylsulphate); paraoxon

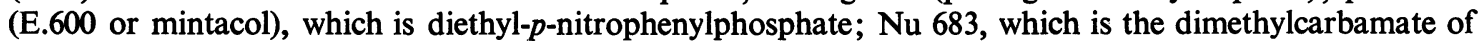
(2-hydroxy-5-phenylbenzyltrimethyl) ammonium bromide; and B.W.284,C.51, which is the dimethobromide of 1 : 5-di ( $p$-N-allyl-N-methylaminophenyl)-pentan-3-one.

\section{RESULTS}

Cholinesterase Inhibitors on the $P-R$ Interval. The duration of the $P-R$ interval was found to be increased by inhibitors of cholinesterase in the heart-lung preparation even when the heart was beating spontaneously. Observations from seven experiments are recorded in Table $I$, in which the corresponding heart rates are also shown. In Experiment 1 the initial heart rate was 142 per min. and the P-R interval was $84 \mathrm{msec}$. In the presence of eserine $2 \times 10^{-6} \mathrm{M}$ the heart rate was reduced to $134 \mathrm{per}$ min. and the P-R interval was increased to $120 \mathrm{msec}$. In Experiment 10 the initial rate was 141 per min. and the P-R interval was $84 \mathrm{msec}$. Neostigmine was then added to the reservoir first in the concentration of $0.6 \times$ $10^{-6} \mathrm{M}$ and later in the concentration $1.8 \times 10^{-6} \mathrm{M}$. This final concentration reduced the spontaneous rate to 84 per min., and lengthened the P-R interval to $136 \mathrm{msec}$. Finally, the injection of $20 \mu \mathrm{g}$. atropine raised the spontaneous rate to $150 \mathrm{per}$ min. and reduced the $P-R$ interval to $80 \mathrm{msec}$, that is to say, restored the initial values. The other experiments in Table $\mathbf{l}$ demonstrate a similar lengthening of $P-R$ interval accompanied by slowing of the spontaneous rate, produced by eserine, by $\mathrm{Nu} 683$, and by paraoxon, the effects in Experiments 16 and 21 being proportional to the concentration of inhibitor added.

TABLE I

Effect of ChE Inhibitors and Atropine on P-R Interval during the Spontaneous Rhythm

\begin{tabular}{|c|c|c|c|c|}
\hline Experiment & Substance added & Concentration & $\underset{\text { (msec.) }}{\text { P-R interval }}$ & $\begin{array}{c}\text { Heart rate } \\
\text { (per min.) }\end{array}$ \\
\hline 1 & $\begin{array}{l}\text { None } \\
\text { Eserine }\end{array}$ & $2 \bar{x}_{10-6 \mathrm{M}}$ & $\begin{array}{r}84 \\
120\end{array}$ & $\begin{array}{l}142 \\
134\end{array}$ \\
\hline 2 & $\begin{array}{l}\text { None } \\
\text { Eserine }\end{array}$ & $2 \overline{\times 10^{-6} \mathrm{M}}$ & $\begin{array}{r}96 \\
120\end{array}$ & $\begin{array}{r}183 \\
98\end{array}$ \\
\hline 8 & $\begin{array}{l}\text { None } \\
\text { Eserine } \\
\text { Atropine }\end{array}$ & $\begin{array}{l}1.5 \times 10^{-5 M} \\
6 \times 10^{-6 \mathrm{~g} .} / \mathrm{ml} .\end{array}$ & $\begin{array}{r}76 \\
128 \\
80\end{array}$ & $\begin{array}{r}172 \\
59 \\
157\end{array}$ \\
\hline 10 & $\begin{array}{l}\text { None } \\
\text { Neostigmine } \\
\text { Atropine }\end{array}$ & $\begin{array}{l}0.6 \times 10^{-6 \mathrm{M}} \\
1.8 \times 10^{-6 \mathrm{M}} \\
2 \times 10^{-6 \mathrm{~g} . / \mathrm{ml} .}\end{array}$ & $\begin{array}{r}84 \\
108 \\
136 \\
80\end{array}$ & $\begin{array}{r}141 \\
116 \\
84 \\
150\end{array}$ \\
\hline 11 & $\begin{array}{l}\text { None } \\
\text { Neostigmine } \\
\text { Atropine }\end{array}$ & $\begin{array}{l}4.5 \times 10^{-6 \mathrm{M}} \\
0.5 \times 10^{-7} \mathrm{~g} . \mathrm{ml}\end{array}$ & $\begin{array}{r}116 \\
152 \\
92\end{array}$ & $\begin{array}{r}117 \\
76 \\
138\end{array}$ \\
\hline 16 & $\begin{array}{c}\text { None } \\
\text { Paraoxon } \\
\quad, " \\
\text { Atropine }\end{array}$ & $\begin{array}{l}9 \times 10^{-6 M} \\
1.8 \times 10^{-5 M} \\
3.6 \times 10^{-5 M} \\
0.7 \times 10^{-7} . / \mathrm{gl} .\end{array}$ & $\begin{array}{r}84 \\
108 \\
124 \\
132 \\
80\end{array}$ & $\begin{array}{r}125 \\
96 \\
74 \\
73 \\
126\end{array}$ \\
\hline 21 & $\begin{array}{l}\text { None } \\
\text { Nu } 683 \\
\text { Neostigmine } \\
\quad,\end{array}$ & $\begin{array}{l} \\
\\
2 \times 10^{-6} \mathrm{M} \\
4.5 \times 10^{-6} \mathrm{M} \\
9 \times 10^{-6} \\
9 \times 10^{-6 M}\end{array}$ & \begin{tabular}{r|}
80 \\
88 \\
112 \\
164 \\
172
\end{tabular} & $\begin{array}{l}146 \\
134 \\
125 \\
119 \\
113\end{array}$ \\
\hline
\end{tabular}


Acetylcholine Infusion on the $P-R$ Interval. In order to compare the results in Table I with those obtained during the infusion of acetylcholine at a constant rate into the blood entering the heart-lung preparation through the superior vena cava, figures are given in Table II for six experiments in which the amounts infused were from 100 to $400 \mu \mathrm{g}$. per min. It can be seen that in every experiment the infusion of acetylcholine produced a lengthening of the P-R interval. The actual amount of acetylcholine required to produce a given percentage change in $\mathbf{P}-\mathrm{R}$ interval varied greatly from dog to dog. For example, the infusion of $400 \mu \mathrm{g}$. acetylcholine per min. in Experiment 9 prolonged the P-R interval only from 112 to 124 msec.; the same rate of infusion in Experiment 28 prolonged the P-R interval from $80 \mathrm{msec}$. to $164 \mathrm{msec}$. The effect of acetylcholine infusions in slowing the pacemaker (Burn, et al., 1955a) exhibited a similar wide range of dose response, and may be related to the amount of circulating cholinesterase.

TABLE II

EfFect of Infusion of ACETyLCHOLINe on P-R InTERVAL

\begin{tabular}{c|c|c|c}
\hline Experiment & $\begin{array}{c}\text { Control P-R } \\
\text { (msec.) }\end{array}$ & $\begin{array}{c}\text { Rate of ACh } \\
\text { infusion per min. } \\
(\mu \mathrm{g} .)\end{array}$ & $\begin{array}{c}\text { P-R during } \\
\text { infusion } \\
\text { (msec.) }\end{array}$ \\
\hline 6 & 76 & 200 & 96 \\
\hline 9 & 112 & 400 & 124 \\
\hline 13 & 84 & 100 & 96 \\
\hline 14 & 92 & 100 & 100 \\
\hline 15 & 104 & 100 & 94 \\
\hline 28 & 200 & 112 \\
& & 400 & 140 \\
\hline
\end{tabular}

Production of Complete $A-V$ Block. The slowing of conduction from the auricle to the ventricle became sufficient to produce complete block when higher concentrations of cholinesterase inhibitors were used. In Experiment 18, paraoxon in concentration $1.8 \times 10^{-5} \mathrm{M}$ caused complete dissociation of auricles and ventricles, the former contracting about 81 per min., and the latter about 37 per min. Electrical stimulation of the auricle then had no effect on the ventricular rate. A slightly higher concentration of paraoxon $\left(2.7 \times 10^{-5} \mathrm{M}\right)$ had the same effect in Experiment 19, when the auricles contracted at 58 per min. and the ventricles at 37 per min. (see Fig. 1). In this experiment also, electrical stimulation of auricles up to 720 per min. did not modify the ventricular rate. Eserine in concentrations of $1.5 \times 10^{-5} \mathrm{M}$ and $3 \times 10^{-5} \mathrm{M}$ in other experiments also produced a complete block.

Effect of Inhibitors on Output. To determine the effect of inhibitors of cholinesterase on output, it was necessary to exclude the effect on the heart rate. A series of observations were therefore made in which the heart was driven electrically at various rates so that the output at a given rate could be compared in the absence of an inhibitor, in its presence, and after the addition of atropine. In some experiments the output fell gradually due to deterioration of the preparation, and the results in Table III have been selected from those experiments in which there was little deterioration. All the results were obtained at rates at which the ventricles followed every beat of the auricles. Table III shows that in three experiments in which eserine, neostigmine, and paraoxon respectively were used, the output in the presence of the inhibitor was less than in the control period, and was also less than in the subsequent period after atropine was given. Experiments 12 and 14 also show that the fall in output due to the presence of the inhibitor was progressively greater at greater rates. The infusion of acetylcholine when the heart was driven at constant rate also caused a fall in output (Burn et al., 1955a).

The Effect of a Period of Electrical Stimulation. The observations thus far described have shown that inhibitors of cholinesterase slow the spontaneous rate of the heart-lung preparation, increase the P-R interval, and reduce the output of blood at a given rate, and that these three effects are abolished by atropine. 


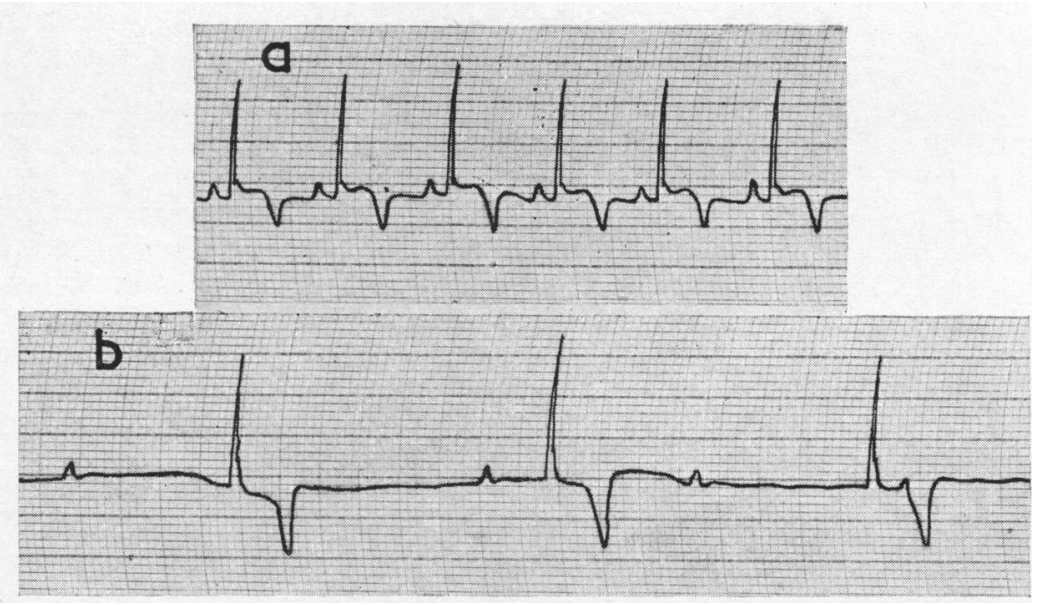

FIG. 1.-Cardiogram of dog heart-lung preparation, (a) in presence of paraoxon $9 \times 10^{-6}$ molar, the rate was slowed to 112 per min.; (b) in presence of paraoxon $2.7 \times 10^{-5}$ molar there was complete block, the auricles and ventricles contracting independently.

TABLE III

Effect of ChE Inhibitors on Output at Constant Rate

\begin{tabular}{|c|c|c|c|c|c|c|}
\hline \multirow[b]{2}{*}{$\begin{array}{c}\text { Experi- } \\
\text { ment }\end{array}$} & \multirow[b]{2}{*}{$\underset{\text { inhibitor }}{\mathrm{ChE}}$} & \multirow[b]{2}{*}{ Concentration } & \multirow[b]{2}{*}{$\begin{array}{l}\text { Driving } \\
\text { rate }\end{array}$} & \multicolumn{3}{|c|}{ Output (ml./15 sec.) } \\
\hline & & & & Control & $\begin{array}{l}\text { In presence } \\
\text { of inhibitor }\end{array}$ & $\underset{\text { atropine }}{\text { After }}$ \\
\hline 9 & Eserine & $0.45 \times 10^{-6} \mathrm{M}$ & $170 / \mathrm{min}$ & 152 & 126 & 150 \\
\hline 12 & $\begin{array}{c}\text { Neostigmine } \\
,,\end{array}$ & $\begin{array}{c}4.5 \times 10^{-6 \mathrm{M}} \\
, "\end{array}$ & $\begin{array}{l}238 \\
248\end{array}$ & $\begin{array}{l}202 \\
182\end{array}$ & $\begin{array}{l}160 \\
112\end{array}$ & $\begin{array}{l}170 \\
166\end{array}$ \\
\hline 14 & $\begin{array}{c}\text { Paraoxon } \\
\text {," } \\
\text { ", }\end{array}$ & $\begin{array}{c}9 \times 10^{-6} \mathrm{M} \\
, " \\
,\end{array}$ & $\begin{array}{l}190 \\
202 \\
216 \\
225\end{array}$ & $\begin{array}{l}186 \\
192 \\
192 \\
186\end{array}$ & $\begin{array}{r}150 \\
126 \\
90 \\
52\end{array}$ & $\begin{array}{r}156 \\
146 \\
120 \\
92\end{array}$ \\
\hline
\end{tabular}

The observations form a suitable prelude to a consideration of the effect of driving the heart electrically. Each period of driving was of similar length and was carried out according to a fixed routine. Stimulation was first applied at a rate about 20 per min. faster than the spontaneous rate. The stimulation was continued for about 40 seconds, during which a cardiogram was taken and the output was measured. Without stopping the stimulation the rate was increased by about 10 per cent and the observations were repeated. In this way the rate was increased up to 550 per min. and the stimulation was then stopped. An electrocardiogram was taken and the output was measured. A pause was then made for about 69 min., when another record was taken and the output measured again. Results from a series of experiments are given in Table IV and they show that the spontaneous rate was always lower at the end of driving than it had been at the beginning, and that in a few minutes it rose again to approximately its original value. Similarly the P-R interval was always longer at the end of driving than it had been before, and after a few minutes it returned towards its normal value. Finally, the output was always less after driving than it had been before, and in a few minutes it increased again. Thus the effect of driving the heart electrically on the spontaneous rate, the P-R interval and the output was the same as the effect of adding an inhibitor of cholinesterase to the preparation when beating at its own rhythm. Moreover, the effect of driving lasted for a few minutes only. The inference is obvious that the procedure of driving may have produced an increased output of acetylcholine, which fell to its original level soon after stimulation was stopped. Further evidence on this will be presented subsequently. 
TABLE IV

To Show Effect of a Period of Electrical Stimulation

Results in the column "After" were obtained immediately after the period of electrical stimulation, and those in the column "Later" 2.5 to 9 min. later

\begin{tabular}{|c|c|c|c|c|c|c|c|c|c|}
\hline \multirow{2}{*}{$\begin{array}{c}\text { Experi- } \\
\text { ment }\end{array}$} & \multicolumn{3}{|c|}{$\begin{array}{l}\text { Spontaneous rate } \\
\text { per min. }\end{array}$} & \multirow[b]{2}{*}{ Before } & \multicolumn{2}{|c|}{$\begin{array}{c}\text { P-R interval } \\
\text { (msec.) }\end{array}$} & \multicolumn{3}{|c|}{$\begin{array}{c}\text { Output } \\
\text { (ml./15 sec.) }\end{array}$} \\
\hline & Before & After & Later & & After & Later & Before & After & Later \\
\hline $\begin{array}{r}1 \\
18 \\
19 \\
21 \\
25 \\
26 \\
27\end{array}$ & $\begin{array}{l}142 \\
158 \\
142 \\
146 \\
117 \\
148 \\
183\end{array}$ & $\begin{array}{l}136 \\
124 \\
125 \\
135 \\
110 \\
137 \\
165\end{array}$ & $\begin{array}{l}146 \\
141 \\
135 \\
141 \\
110 \\
143 \\
187\end{array}$ & $\begin{array}{r}84 \\
100 \\
90 \\
80 \\
80 \\
63 \\
82\end{array}$ & $\begin{array}{r}99 \\
124 \\
110 \\
92 \\
98 \\
104 \\
101\end{array}$ & $\begin{array}{r}92 \\
108 \\
66 \\
84 \\
88 \\
63 \\
81\end{array}$ & $\begin{array}{l}124 \\
104 \\
140 \\
154 \\
116 \\
150 \\
190\end{array}$ & $\begin{array}{r}110 \\
92 \\
118 \\
144 \\
88 \\
126 \\
168\end{array}$ & $\begin{array}{l}126 \\
146 \\
144 \\
152 \\
116 \\
134 \\
194\end{array}$ \\
\hline
\end{tabular}

Action of Inhibitors during Electrical Stimulation. When the heart is driven electrically at increasing rates it is well known that at a certain critical rate a point is reached at which the ventricles no longer follow the auricles and some degree of A-V block begins. The presence of inhibitors of cholinesterase facilitated the appearance of such partial A-V block with great regularity.

In Fig. 2 the ventricular rate expressed as a percentage of the auricular rate is plotted as ordinate, and the rate of stimulation as abscissa. The ventricular rate remained the same as the auricular rate up to 300 stimuli per min., but above this the ventricular rate fell until it was 50 per cent of the auricular rate at 383 stimuli per min. The $2: 1$ block thus established persisted up to 550 stimuli per min. When eserine was added to make a concentration of $4.5 \times 10^{-6} \mathrm{M}(1.35 \mathrm{mg}$. in $900 \mathrm{ml}$.), and the stimulation at increasing rates was repeated, block occurred at much lower rates, so that the whole curve was shifted to the left (Fig. 2, B). The ventricular rate fell below the auricular rate when the rate of stimulation was only 214 per min., and a $2: 1$ rhythm began at 274 stimuli per min. At 440 stimuli per min. the ventricular beats were 45 per cent of the auricular beats, and at 576 stimuli per min. the block was $4: 1$.

Stimulation was then stopped, and $30 \mu \mathrm{g}$. atropine was injected into the blood, entering the cannula in the superior vena cava. When stimulation at increasing rates was repeated for a third time, the ventricular rate followed the course it took during the first period of stimulation before eserine was added (Fig. 2, C). The small amount of atropine therefore abolished the action of eserine.

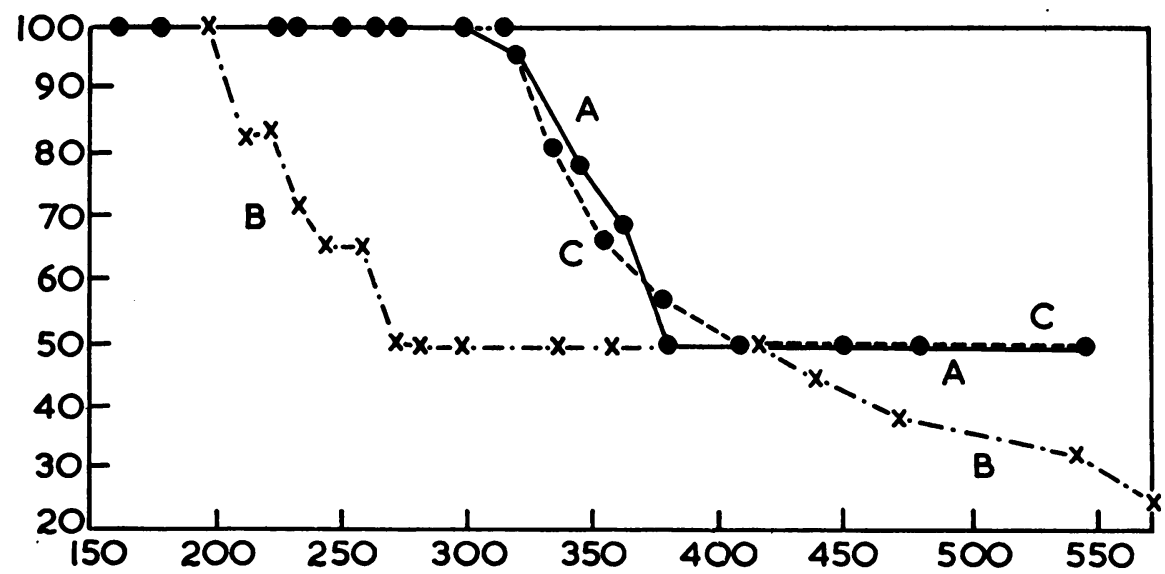

FIG. 2.-Heart-lung preparation driven by electrical stimulation. Abscissa: rate of stimulation per min. Ordinate: percentage of auricular beats transmitted to the ventricles. (A) Shows control observations; (B) shows observations in the presence of eserine $4.5 \times 10^{-6}$ molar; (C) shows observations then made after the injection of $30 \mu \mathrm{g}$. atropine. 
The Effect of Atropine. It has been shown that the injection of a small amount of atropine abolished the action of eserine in shifting the onset of block to a lower rate. It was of interest, therefore, to determine whether a larger amount of atropine might shift the curve to the right, i.e. to delay the onset of block until a higher rate of stimulation was reached. That this was, in fact, the case is shown in Experiment 10 of Table V, in which the presence of atropine $0.3 \times 10^{-5} \mathrm{~g} . / \mathrm{ml}$. shifted the point of onset of block from 225 to 280 stimuli per minute, and the onset of $2: 1$ block from 270 to 350 stimuli per minute. Hexamethonium, on the other hand, had no effect upon the onset of block (Table V, Experiment 24).

\section{TABLE V}

Change in A-V Conduction by Neostigmine and Atropine

Figures are rate/min. $\quad \mathrm{V}=$ ventricular rate. $\mathrm{A}=$ auricular rate

\begin{tabular}{|c|c|c|c|}
\hline Experiment & Conditions & $\begin{array}{l}\text { Maximum rate of } \\
\text { stimulation for } \\
\qquad \mathbf{V}=\mathbf{A}\end{array}$ & $\begin{array}{l}\text { Minimum rate of } \\
\text { stimulation for } \\
\qquad V=\frac{1}{2} A\end{array}$ \\
\hline 10 & $\begin{array}{l}\text { First control } \\
\text { Second , } \\
\text { Third }, \\
\text { Neostigmine } \\
0.6 \times 10^{-6} \mathrm{M} \\
1.8 \times 10^{-6} \mathrm{M} \\
\text { Atropine } \\
0.3 \times 10^{-7} \mathrm{~g} . / \mathrm{ml} . \\
0.3 \times 10^{-5} \mathrm{~g} . / \mathrm{ml} \text {. }\end{array}$ & $\begin{array}{r}225 \\
215 \\
222 \\
183 \\
83 \\
254 \\
280\end{array}$ & $\begin{array}{l}270 \\
281 \\
278 \\
220 \\
108 \\
305 \\
350\end{array}$ \\
\hline 24 & $\begin{array}{l}\text { First control } \\
\text { Second },, \\
\text { Neostigmine } \\
3.0 \times 10^{-6} \mathrm{M} \\
\text { Hexamethonium } \\
10^{-5} \mathrm{~g} . / \mathrm{ml} \text {. } \\
\text { Atropine } \\
0.5 \times 10^{-7} \mathrm{~g} . / \mathrm{ml} \text {. }\end{array}$ & $\begin{array}{l}298 \\
298 \\
255 \\
261 \\
300\end{array}$ & $\begin{array}{l}384 \\
380 \\
350 \\
345 \\
366\end{array}$ \\
\hline
\end{tabular}

The procedure of driving does not itself affect the rate at which block first makes its appearance. Evidence for this is also presented in Table V. In Experiment 10, there were three control periods of increasing stimulation, and in all three the rates of stimulation above which the ventricle began to miss beats, and at which the $2: 1$ rhythm developed were almost the same. In Experiment 24 there were two control periods.

The Effect of Block on Output. In a recent paper (Burn et al., 1955b) direct experimental evidence was presented of the beneficial effect on cardiac output of the onset of A-V block or of auricular fibrillation. In the present series of experiments also it was found that when the heart was driven at increasing rates, the output of blood varied directly as the ventricular rate when that rate was low, and inversely as the ventricular rate when that rate was high. The onset of block therefore modified the output. An example is given in Fig. 3. Fig. $3 a$ shows results obtained in the control period at the beginning of the experiment. As the ventricular rate rose to $286 / \mathrm{min}$. the output fell from $194 \mathrm{ml} . / 15 \mathrm{sec}$. to $22 \mathrm{ml} . / 15 \mathrm{sec}$. When the ventricular rate fell as block began, the output rapidly recovered, and with higher rates of stimulation the record of its change was approximately the inverse of that of the ventricular rate. After the control observations were made, neostigmine was added, the concentration being $4.5 \times 10^{-6} \mathrm{M}$. When the heart was stimulated at increasing rates, the relation between ventricular rate and output was that shown in Fig. $3 \mathrm{~b}$. Owing to the early incidence of block, the ventricle ceasing to follow the auricle above 158 per min., the ventricular rate was throughout much slower, and the output of blood followed the ventricular rate closely. The fall in output seen in Fig. 3a at a rate of stimulation of $286 / \mathrm{min}$. was absent. These observations illustrate the value of block in preventing a fall in output due to a too rapid ventricular rate. When the observations in the presence of neostigmine were complete, atropine was injected and the observations shown in Fig. $3 \mathrm{c}$ were made, which were very similar to those in Fig. 3a. 


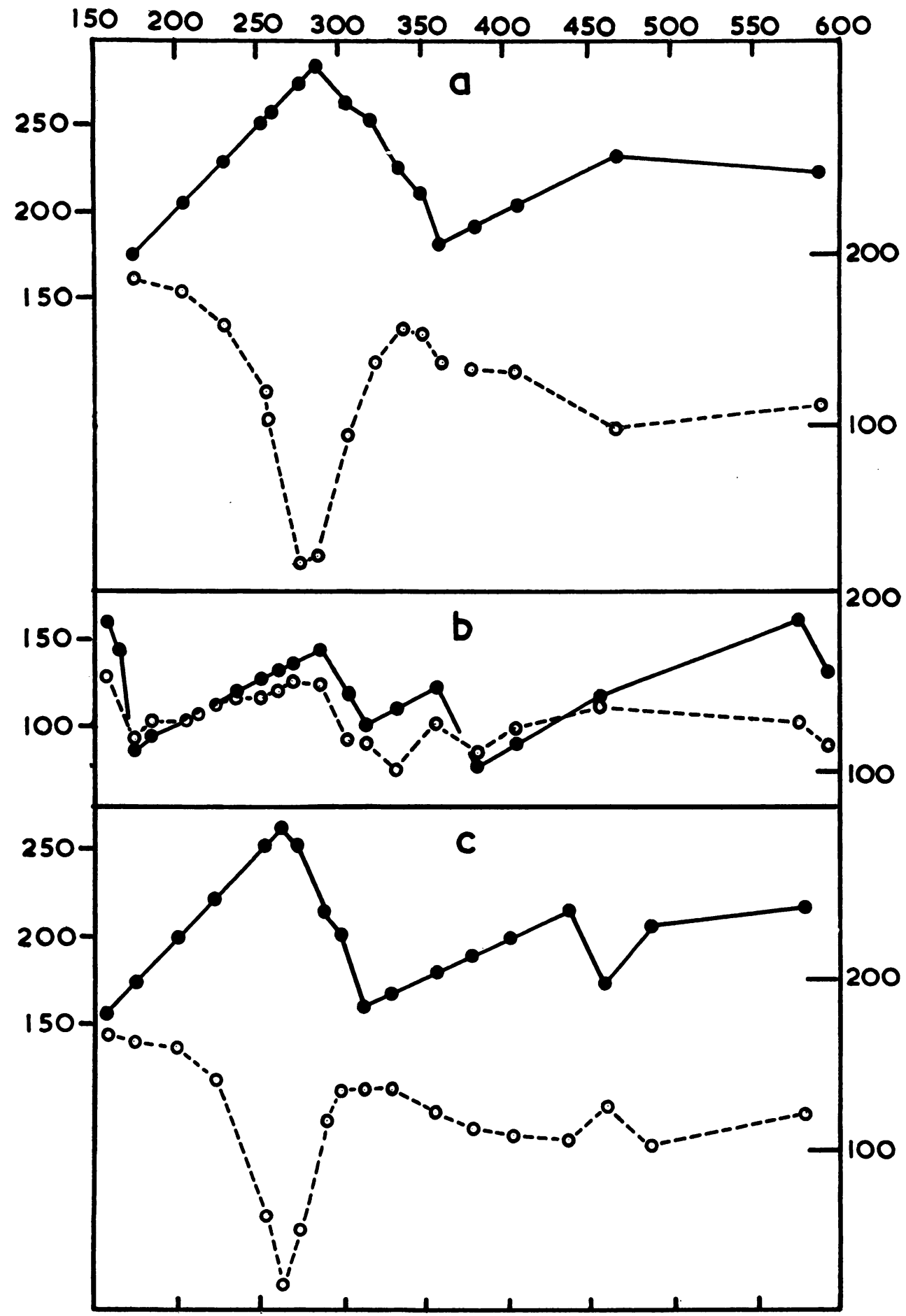

FIG. 3.-Heart-lung preparation driven by electrical stimulation. Abscissa: rate of stimulation per min. Ordinate: in all three parts of the figure, the ordinate on the left is the ventricular rate which is plotted as black circles with a continuous line; the ordinate on the right is the output of blood per $15 \mathrm{sec}$. which is plotted as white circles with a dotted line. (a) Shows control observations; (b) shows observations in the presence of neostigmine $4.5 \times$ $10^{-6}$ molar; (c) shows observations after the injection of $50 \mu \mathrm{g}$. atropine. 
Effect of Varying Concentrations. The effects of varying concentrations of an inhibitor were tested in several experiments. An example of the effects of varying concentrations of paraoxon is given in Fig. 4; each concentration has been calculated on the assumption that the paroxan at our disposal was 100 per cent pure and the concentrations may therefore have been less than stated; the relative values would remain the same. The concentrations are shown on the abscissa on a logarithmic scale; the ordinates are the rates of stimulation. Curve $\mathrm{A}$ indicates the effect of increasing concentrations of paraoxon on the maximum rate at which the ventricles followed the auricles. Curve $B$ is the effect on the minimum rate at which a $2: 1$ rhythm was seen. Curve $C$ is the effect on the maximum rate at which a $2: 1$ rhythm was seen, i.e. above this rate the block became greater than $2: 1$.

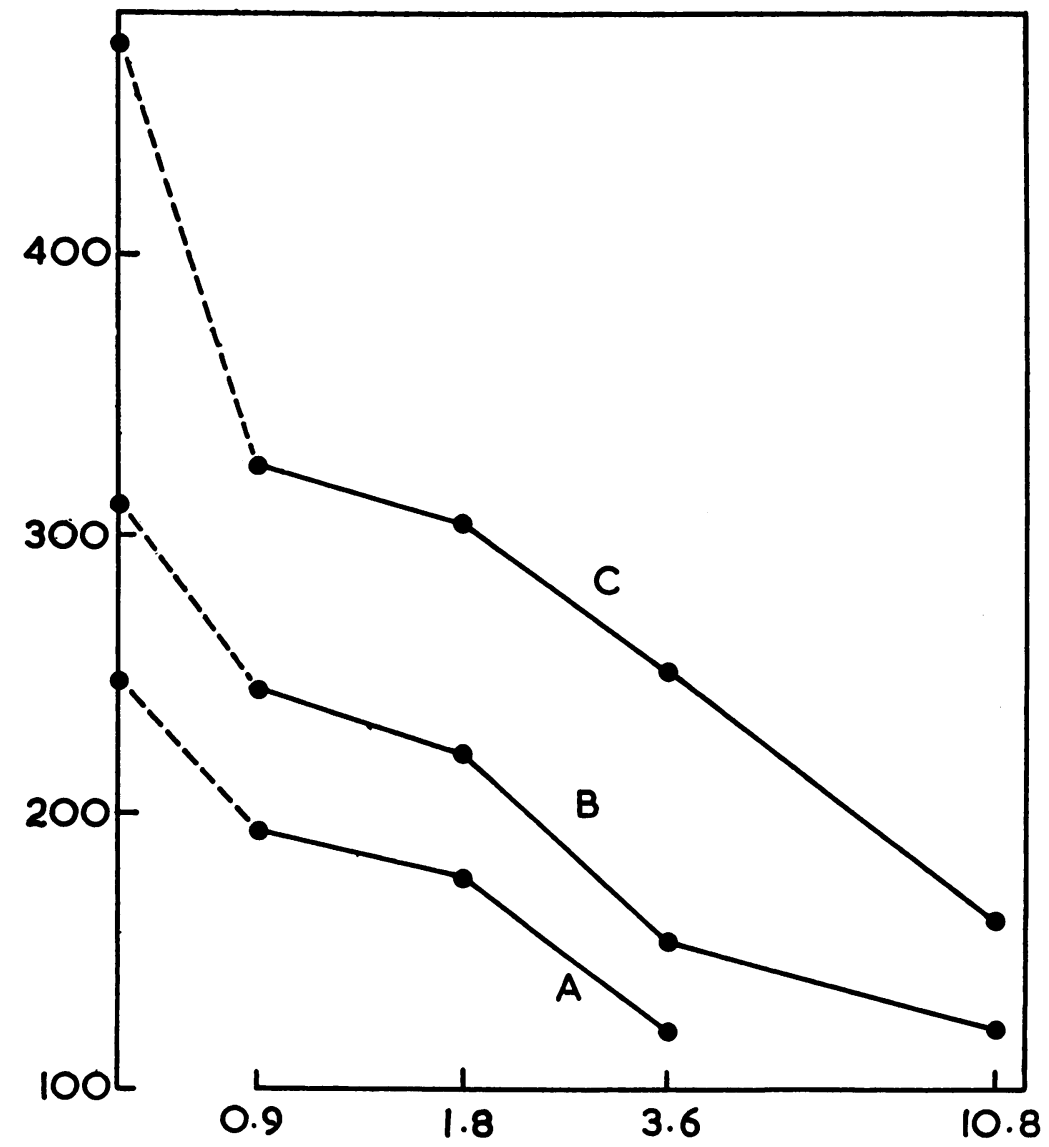

FIG. 4.- Heart-lung preparation driven electrically. Abscissa: concentration $\times 10^{-5}$ molar of paraoxon shown on a logarithmic scale. Ordinate: rate of stimulation per min. (A) Shows the maximum rate of stimulation at which the ventricles followed all contractions of the auricles; (B) shows the minimum rate of stimulation at which a $2: 1$ block was seen. (C) shows the maximum rate of stimulation for $2: 1$ block; at higher rates the block was more than $2: 1$. All these rates declined as the concentration of paraoxon rose.

Regularity of the Effect on Block. The effects described were produced with great regularity, as the list of observations given in Table VI shows. The only exception was when B.W.284.C.51 was used, which shifted the onset of block to a slightly higher rate in the two experiments in which it was tried. Recently Tedeschi (1954) has obtained evidence that several inhibitors of cholinesterase have an atropine-like action on cardiac tissue, and that B.W.284.C.51 possesses this action to a greater extent than do the others. He found that neostigmine also had some atropine-like action, and this may explain why we obtained a much 
smaller effect than usual when we added as much as $6 \mathrm{mg}$. to 1 litre of blood at the beginning of one experiment. Tedeschi observed that the organic phosphate inhibitors such as paraoxon were without atropinelike action, and this substance always produced effects that increased with the concentration as shown in Fig. 4.

TABLE VI

Effect of Inhibitors of ChE on Rate of Stimulation at which Block Occurred

Figures are rates per minute.

\begin{tabular}{|c|c|c|c|c|c|}
\hline \multirow[b]{2}{*}{$\begin{array}{l}\text { Experi- } \\
\text { ment }\end{array}$} & \multirow[b]{2}{*}{ Inhibitor } & \multirow[b]{2}{*}{$\begin{array}{c}\text { Molar } \\
\text { concentration }\end{array}$} & \multicolumn{2}{|c|}{ Maximum rate at which $\mathbf{V}=\mathbf{A}$} & \multirow[b]{2}{*}{$\begin{array}{l}\text { Drop } \\
\text { in rate }\end{array}$} \\
\hline & & & $\begin{array}{l}\text { Before inhibitor } \\
\text { was added }\end{array}$ & $\begin{array}{l}\text { In presence } \\
\text { of inhibitor }\end{array}$ & \\
\hline $\begin{array}{r}1 \\
2 \\
3 \\
4 \\
5 \\
6 \\
7 \\
8 \\
9 \\
10 \\
11 \\
12 \\
13 \\
14 \\
15 \\
16 \\
17 \\
18 \\
19 \\
20 \\
21 \\
22 \\
23\end{array}$ & 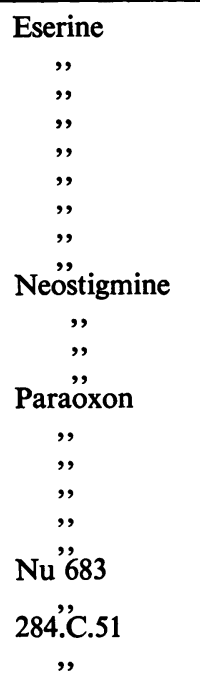 & 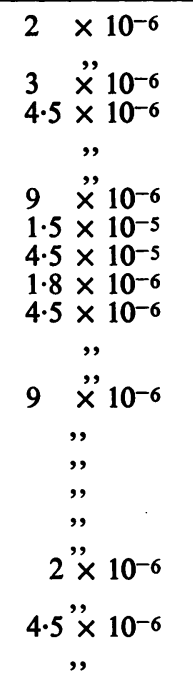 & $\begin{array}{l}228 \\
256 \\
253 \\
300 \\
322 \\
272 \\
280 \\
327 \\
185 \\
222 \\
200 \\
286 \\
286 \\
263 \\
225 \\
246 \\
267 \\
205 \\
251 \\
268 \\
246 \\
259 \\
310\end{array}$ & \begin{tabular}{|l|}
168 \\
148 \\
163 \\
197 \\
266 \\
201 \\
218 \\
138 \\
94 \\
83 \\
107 \\
244 \\
158 \\
225 \\
184 \\
194 \\
171 \\
132 \\
188 \\
232 \\
198 \\
268 \\
338
\end{tabular} & $\begin{array}{r}60 \\
108 \\
90 \\
103 \\
56 \\
71 \\
62 \\
89 \\
91 \\
139 \\
93 \\
42 \\
128 \\
38 \\
41 \\
52 \\
96 \\
73 \\
63 \\
36 \\
48 \\
0 \\
0\end{array}$ \\
\hline
\end{tabular}

Speed of Onset of Block. In some experiments a study was made of the speed at which block developed when the auricle was stimulated at a high rate. By stimulating at increasing rates, a rate was determined at which a $4: 3$ or a $3: 2$ block was produced. The stimulation was then stopped, and after a few minutes it was begun again at that particular rate. A continuous electrocardiogram record was taken for about 2 minutes from the start of the stimulation. It was found that when the stimulation was applied the ventricle at first followed every beat of the auricle, and that thereafter block developed gradually as shown in Fig. 5(I). An inhibitor of cholinesterase was then added to the blood, and stimulation at the same rate was repeated. Fig. 5(II) shows the effect of $0.3 \mathrm{mg}$. eserine in 1 litre of blood, making a concentration $10^{-6} \mathrm{M}$. The speed of onset of the block was now much faster than before. Atropine was then injected and stimulation applied again; the speed of onset of block was rather less than in the control period, Fig. 5(III). These observations showed that the block present at any rate of stimulation depended to some extent on the length of time for which the stimulation had been applied, the full degree of block that the stimulus produced appearing in about one minute.

Effect of Stimulation on $P-R$ Interval. When the heart was driven at increasing rates the $P-R$ interval was observed to become longer, but the increase in the interval for a given increase in rate was greater in the presence of an inhibitor of cholinesterase. The observations in Fig. 6 taken from Experiment 10 were typical of those made in six experiments in which the P-R interval was measured. Curve 1 in Fig. 6 shows at the left end the $\mathbf{P}-\mathbf{R}$ interval when the heart was beating spontaneously at the rate indicated. The four succeeding points were recorded during electrical stimulation. Curve 2 was obtained by repeating the rates of stimulation; all P-R intervals were longer but Curve 2 was approximately parallel to Curve 1 . A third repetition of the rates of stimulation gave results coinciding with those in Curve 2. Neostigmine was then added to make a concentration of $0.6 \times 10^{-6} \mathrm{M}$, and in its presence the rates of stimulation were repeated 


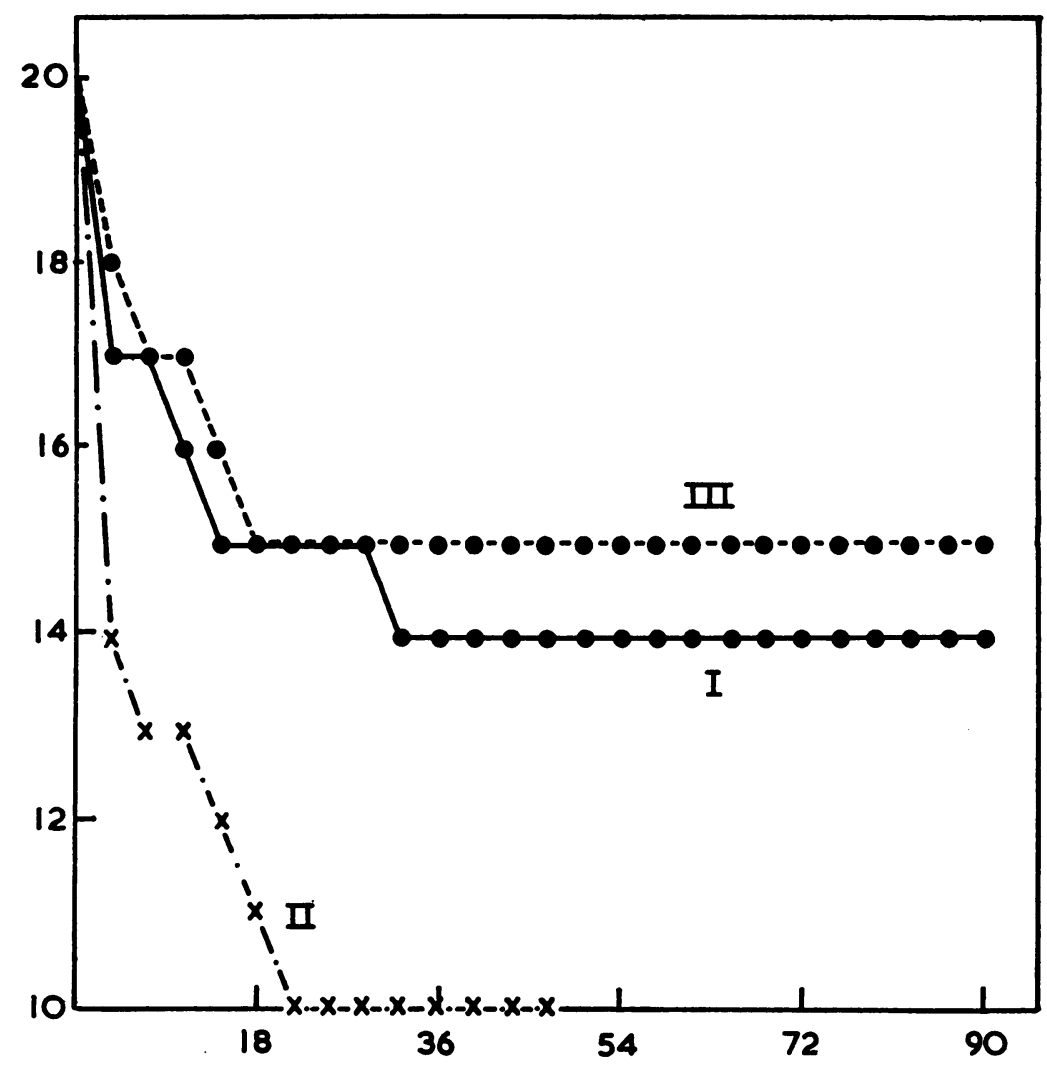

FIG. 5.-Heart-lung preparation of dog. Auricles stimulated at 330 per min. Abscissa: time in seconds from beginning of stimulation. Ordinate: number of stimuli transmitted to ventricles out of each successive 20 stimuli. Graph I shows control observations. Graph II shows observations in the presence of i serine $10^{-6}$ molar. Graph III shows observations after the injection of $0.2 \mathrm{mg}$. atropine.

for the fourth time. The results were those in Curve 3 which was approximately parallel to Curves 1 and 2 at its left end, but at its right end rose more steeply upwards. A further addition of neostigmine which brought the concentration to $1.8 \times 10^{-6} \mathrm{M}$ caused the spontaneous rate to fall to 83 per min. (see Curve 4) and the P-R interval to rise to $134 \mathrm{msec}$; when the heart was stimulated electrically at the same rate the P-R interval rose to $157 \mathrm{msec}$. Finally, atropine was injected, and Curve 5 was then obtained with shorter P-R intervals for a given rate of stimulation than those in Curve 1. These results were to be expected in view of the findings already described that (1) the presence of a ChE inhibitor increased the P-R interval when the heart was beating spontaneously in spite of slowing the rate, this increase being abolished by atropine, and that (2) the P-R interval was increased at the end of a period during which the heart was stimulated electrically at increasing rates.

Production of Cardiac Arrest. In some experiments, electrical stimulation in the presence of an inhibitor of cholinesterase led to ventricular arrest. Thus in one experiment the addition of neostigmine in concentration $1.8 \times 10^{-6} \mathrm{M}$ reduced the spontaneous rate to $83 \mathrm{per}$ min., and the ventricle ceased to follow all beats of the auricle during stimulation at so low a rate as 97 per min. When the rate of stimulation was 198 per min. there was a block of $6: 1$ as shown in Fig. $7 \mathrm{a}$. When the rate was raised to 243 per min. there was not only complete block but also disappearance of all ventricular activity. The rate of stimulation was reduced (Fig. 7c) and then stimulation was stopped, at which point all cardiac activity ceased (Fig. 7d). An injection of $20 \mu \mathrm{g}$. atropine was made into the ventricle, and the ventricle was squeezed to drive the blood into the aorta and so to the coronary circulation. The first sign of recovery of activity was auricular 


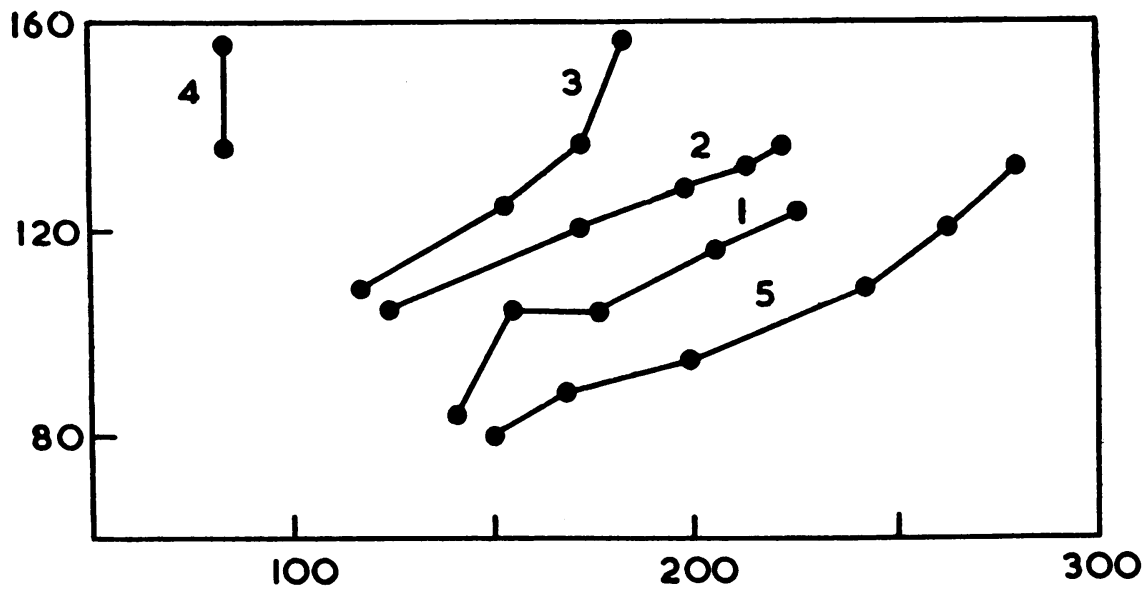

FIG. 6.-Heart-lung preparation. Abscissa: heart rate per min. Ordinate: duration of $\mathbf{P}-\mathbf{R}$ interval in msec. Curve 1 shows the increase in $\mathbf{P}-\mathbf{R}$ interval during the first period in which the heart was driven electrically. Curve 2 shows the increase in the P-R interval in the second and third periods in which the heart was driven electrically. Curve 3 shows the increase in the presence of neostigmine $0.6 \times 10^{-6}$ molar. Curve 4 shows the increase in the presence of neostigmine $1.8 \times 10^{-6}$ molar. Curve 5 shows the increase after the injection of $2 \mathrm{mg}$. atropine.

fibrillation (Fig. 7e) which changed through auricular flutter (Fig. 7f) to a slow auricular rhythm at the rate of 95 per min. (Fig. 7g). Ventricular complexes then began (Fig. 7h), and a $2: 1$ rhythm was established (Fig. 7i). Normal rhythm finally returned at a rate of 118 per min. (Fig. 7j).

Production of Auricular Fibrillation. We have already shown that when acetylcholine is infused at a constant rate into the blood reaching the heart, and electrical stimulation is applied, auricular fibrillation occurs (Burn et al., 1955a). We were therefore anxious to know whether auricular fibrillation could be produced by stimulation in the presence of an inhibitor of cholinesterase. For this purpose we used higher concentrations of an inhibitor than for the previous observations, and in order to avoid the atropine-like action that higher concentrations of some inhibitors possess, we chose paraoxon. Results of three experiments are given in Table VII, in each of which fibrillation was produced with three concentrations of paraoxon, the last column showing the period for which fibrillation continued after the stimulation was stopped. When auricular fibrillation was produced by electrical stimulation during the infusion of acetylcholine, the fibrillation continued after stimulation stopped for so long as the acetylcholine was infused. In the experiments with paraoxon fibrillation was only temporary; when stimulation was stopped it continued for some time and then stopped spontaneously. The length of time was, however, greater when the concentration of paraoxon was greater. In two experiments fibrillation occurred during stimulation in the presence of eserine. In Experiment 2 the concentration of eserine was $2 \times 10^{-6} \mathrm{M}$ and the rate of stimulation was 570 per min. In Experiment 8, the concentration of eserine was $5 \times 10^{-5} \mathrm{M}$ and the rate of stimulation was 560 per min. In both experiments fibrillation stopped within a few seconds when stimulation was stopped.

Thus auricular fibrillation was produced by a high rate of stimulation in the presence of three different concentrations of paraoxon in each of three experiments. However, the conditions for the appearance of fibrillation appeared to change slightly in the course of a few minutes. In Fig. 8a fibrillation had been induced and continued when stimulation stopped. The normal rhythm returned as seen in Fig. 8b, and stimulation was begun again at the same rate as before; after 9 stimuli there was complete A-V block with absence of ventricular activity, but the auricles followed each stimulus and did not fibrillate again. In Fig. 8c ventricular complexes returned. In another experiment the reverse happened. The auricles responded to every stimulus up to 1256 per min., but when stimulation was stopped, and then turned on again after 2 minutes, auricular fibrillation began at once.

Fibrillation with Eserine and Acetylcholine. In the previous work in which it was shown that stimulation during the infusion of acetylcholine at constant rate caused auricular fibrillation, the amounts of acetylcholine required varied from $40 \mu \mathrm{g}$. per min. to $3.2 \mathrm{mg}$. per min. We therefore determined the amount of 


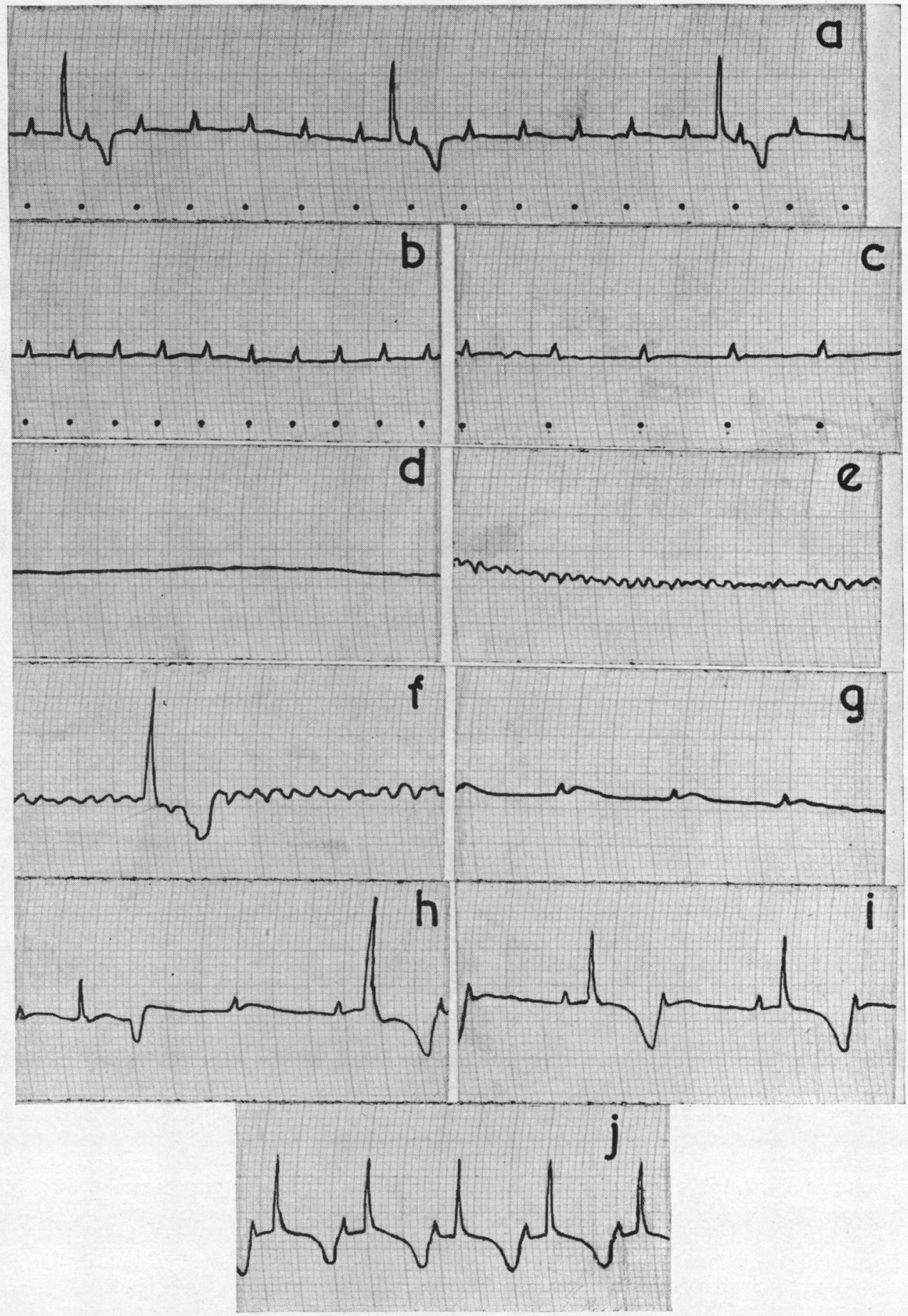

FIG. 7.-Cardiogram of heart-lung preparation. The stimuli are marked by dots. (a) Shows the $6: 1$ block in the presence of neostigmine $1.8 \times 10^{-6}$ molar when the rate of stimulation was 198 per min.; (b) shows complete block with absence of ventricular activity when the rate of stimulation was raised to 243 per min.; (c) shows the persistence of this block when the rate was decreased to 120 per min.; (d) shows complete arrest of the heart when the stimulus was stopped. $20 \mu \mathrm{g}$ atropine was then injected into the left ventricle, and the ventricles were squeezed two or three times to expel the blood; (e) shows auricular fibrillation; (f) shows fibrillation becoming more like flutter; $(\mathrm{g})$ shows a spontaneous auricular rhythm; (h) shows the beginning of ventricular spikes; (i) shows a rhythm with $2: 1$ block; (j) shows a normal rhythm. 
TABLE VII

Production of Fibrillation

\begin{tabular}{|c|c|c|c|c|}
\hline Experiment & Inhibitor & $\begin{array}{c}\text { Molar } \\
\text { concentration }\end{array}$ & $\begin{array}{l}\text { Rate of } \\
\text { stimulation } \\
\text { per min. }\end{array}$ & $\begin{array}{l}\text { Duration of fibrillation } \\
\text { when stimulus stopped }\end{array}$ \\
\hline 17 & $\begin{array}{c}\text { Paraoxon } \\
,, \\
,,\end{array}$ & $\begin{array}{r}9 \times 10^{-6} \\
1.8 \times 10^{-5} \\
3.6 \times 10^{-5}\end{array}$ & $\begin{array}{l}556 \\
556 \\
562\end{array}$ & $\begin{array}{l}1 \mathrm{~min} . \\
3.3 \mathrm{~min} . \\
9.6 \mathrm{~min} .\end{array}$ \\
\hline 18 & $\begin{array}{c}\text { Paraoxon } \\
,, \\
,\end{array}$ & $\begin{array}{r}9 \times 10^{-6} \\
2 \cdot 7 \times 10^{-5} \\
10^{-4}\end{array}$ & $\begin{array}{r}330 \\
750 \\
1256\end{array}$ & $\begin{array}{c}5 \mathrm{~min} . \\
25 \mathrm{~min} \text {. } \\
\text { (Stopped by atropine) }\end{array}$ \\
\hline 19 & $\begin{array}{c}\text { Paraoxon } \\
,, \\
,,\end{array}$ & $\begin{array}{r}9 \times 10^{-6} \\
2.7 \times 10^{-5} \\
6.3 \times 10^{-5}\end{array}$ & $\begin{array}{l}708 \\
875 \\
865\end{array}$ & $\begin{array}{l}\text { (Flutter } 10 \mathrm{sec} . \text { ) } \\
1 \mathrm{~min} . \\
10 \mathrm{~min} .\end{array}$ \\
\hline
\end{tabular}

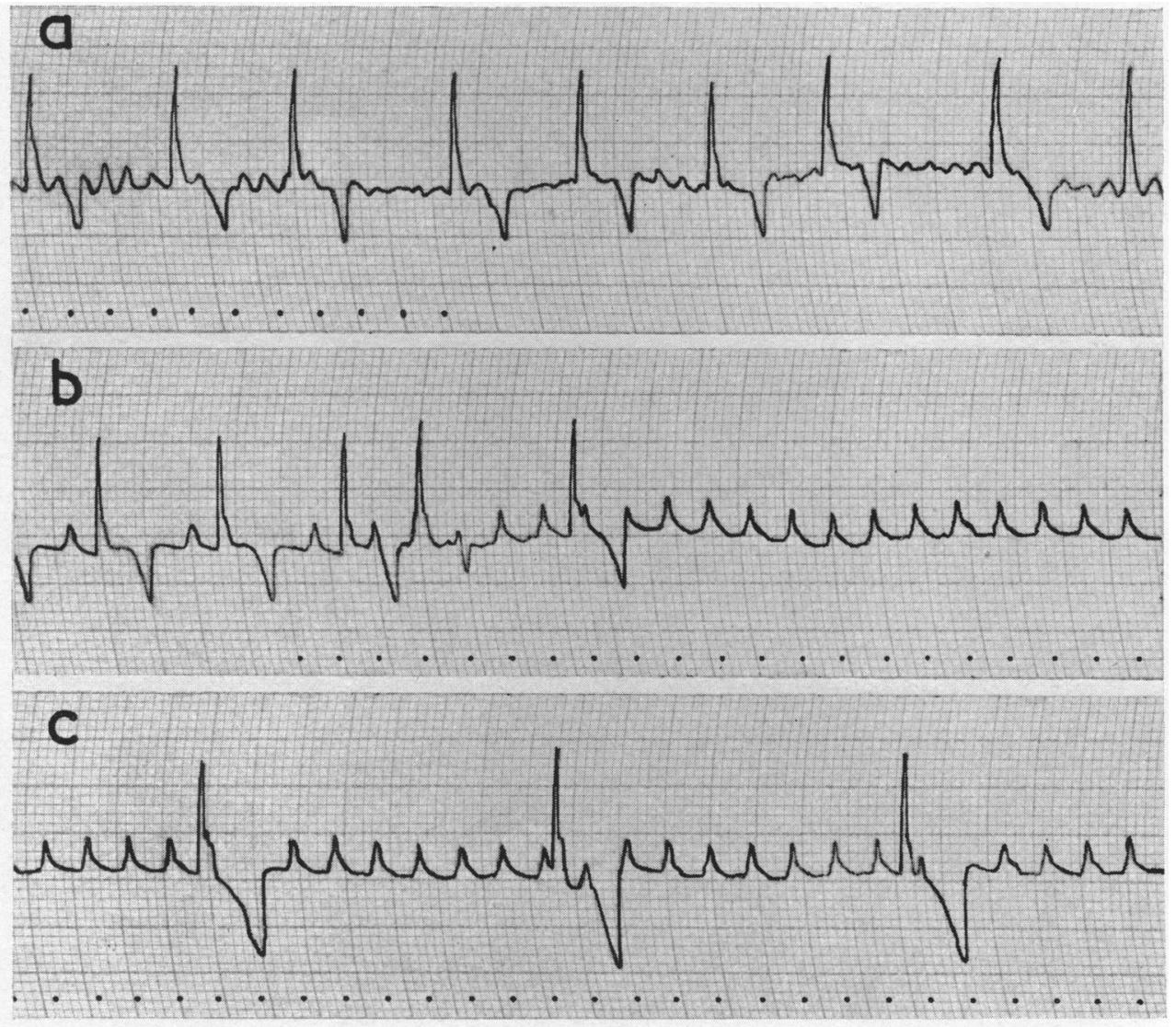

FIG. 8.-Cardiogram of heart-lung preparation. (a) Shows a mixture of auricular flutter and fibrillation in the presence of paraoxon $\left(9 \times 10^{-6}\right.$ molar $)$ during stimulation at 330 per min. The stimuli are marked by the dots. This continued for $5 \mathrm{~min}$. after cessation of the stimulation. (b) Shows the restored normal rhythm and the complete block produced by resuming the same rate of stimulation; (c) shows the persistence of the block, the ventricular waves being unrelated to the auricular waves. 
acetylcholine required in two experiments in which eserine was added to the blood before infusion with acetylcholine began.

In Experiment 2 the amount of eserine added was $0.75 \mathrm{mg}$. to 1 litre of blood, so that the concentration was $2 \times 10^{-6} \mathrm{M}$, and infusion of acetylcholine began at $3.5 \mu \mathrm{g}$. per min. Fibrillation was seen when the rate of stimulation was 190 per min. and continued when the stimulation was stopped (see Fig. 9a). After 5 minutes the acetylcholine infusion was reduced to $2 \mu \mathrm{g}$. per min., and after 4 minutes more it was reduced to $1 \mu \mathrm{g}$. per min. After 6 minutes more fibrillation continued and the infusion of acetylcholine was stopped. After one minute fibrillation changed to flutter (Fig. 9b), and then there was a return to normal rhythm (Fig. 9c). In Experiment 1, in the presence of the same amount of eserine, fibrillation continued for $25 \mathrm{~min}$. during the infusion of acetylcholine at the rate of $3.25 \mu \mathrm{g}$. per min. These results showed that in the presence of a low concentration of eserine, very small amounts of acetylcholine maintained fibrillation once it had begun.

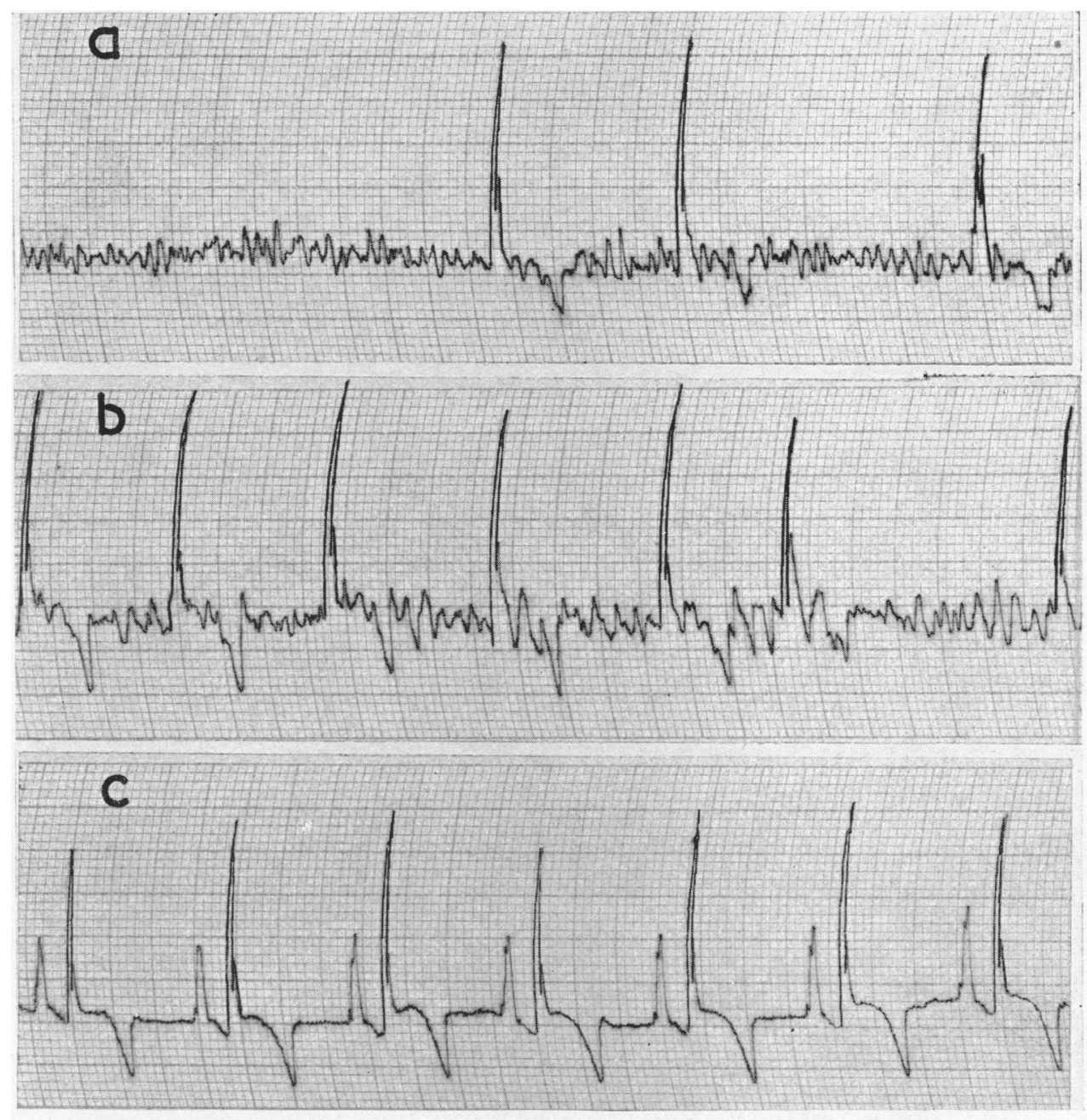

FIG. 9.-Cardiogram of heart-lung preparation. (a) Shows auricular fibrillation produced by stimulation at 190 per min. in the presence of eserine $2 \times 10^{-6}$ molar and during the infusion of acetylcholine at $3.5 \mu \mathrm{g}$. per min. The stimulation was stopped, but the fibrillation persisted so long as the infusion of acetylcholine continued. (b) Shows that after the infusion of acetylcholine was stopped, the fibrillation became more like flutter, and the number of ventricular complexes increased. (c) Shows the return to normal rhythm. 


\section{DisCUSSION}

When acetylcholine is infused at constant rate into the blood of a heart-lung preparation, the pacemaker is slowed, the $\mathrm{P}-\mathrm{R}$ interval is prolonged, and the output is observed to decline when the rate is kept constant by electrical stimulation. When the auricles are stimulated electrically at increasing rates, the infusion of acetylcholine lowers the rate of stimulation at which the ventricles cease to respond to every impulse arriving from the auricles. Finally, when the amount of acetylcholine infused per min. is sufficiently high (though for some preparations this amount is not great) electrical stimulation leads to the onset of auricular fibrillation.

The observations that have now been described show that the addition of any one of a number of inhibitors of cholinesterase to the blood has in general the same effects, and that these effects are abolished by atropine. The inference is that acetylcholine is being liberated in the heart-lung preparation, although the vagus nerves are cut, and no stimulation is being applied to them. This liberation of acetylcholine might be from the heart or from the lungs. However, the observations also show that when the heart is driven electrically in the absence of any cholinesterase inhibitor, at the end of the period of stimulation there is a slowing of the pacemaker, a prolongation of the $\mathrm{P}-\mathrm{R}$ interval, and a diminution of the output, all three changes diminishing in the course of a few minutes. Thus the electrical stimulation appears to cause an increase of a substance in the blood that has the properties of acetylcholine and like it is rapidly destroyed. These observations point to the heart as the source of the acetylcholine that is liberated rather than to the lungs. This evidence is supported by the finding mentioned earlier that the isolated rabbit heart beating spontaneously liberates a substance that in pharmacological tests on other tissues behaves like acetylcholine.

The question then arises from where in the heart is the acetylcholine liberated? During electrical stimulation of the auricles the acetylcholine might be supposed to come from the vagus nerve endings, which might be stimulated directly by the current applied to the auricles. Each shock was, however, only $1 \mathrm{~mA}$ in strength and of $0.9 \mathrm{msec}$. duration, and was applied to the tip of the right auricle. It is unlikely that so mild a stimulus was able to do more than set up a propagated disturbance or that it stimulated other vagal endings than those immediately beneath the electrodes since the nerves in the auricle do not form a syncytium. Electrical stimulation of vagal nerve endings could not in any case account for the effects of inhibitors of cholinesterase on spontaneous rates and on conduction that were seen when no stimulation was applied. Hence the possibility arises that the acetylcholine might come from some non-nervous source. Recently Bülbring $e t$ al. (1953) have found that the rhythmic movements of the cilia on the gill plates of Mytilus edulis are controlled by acetylcholine formed locally in tissue that contains no nervous elements, and as long ago as 1924 Gray drew attention to the close similarity in the responses of these same cilia and of those of the sinus region of the frog heart to a wide variety of changes.

While the effect of adding inhibitors of cholinesterase to the blood in the heart-lung preparation was in general similar to that of infusing acetylcholine, there were points of difference. The effect of inhibitors of cholinesterase in slowing the pacemaker and in lowering the rate at which A-V conduction began to be interrupted was much greater than that of infusions of acetylcholine even when the amounts infused were large. These differences suggested that acetylcholine produced within the heart had readier access to the pacemaker and to the A-V bundle than that coming in the blood stream. There was also the difference that when auricular fibrillation was produced by stimulation during infusion of acetylcholine, it persisted after the stimulation stopped for so long as the acetylcholine was infused; on the other hand, when fibrillation was produced by stimulation in the presence of a cholinesterase inhibitor, it stopped soon after the stimulation stopped. This fact, taken in conjunction with the observation that the time fibrillation then lasted was greater in proportion to the amount of cholinesterase inhibitor present, suggests that the fibrillation was due to the acetylcholine liberated by driving the heart at high rates. It is thus possible that the observation made by Rothberger and Winterberg (1910) that driving the heart at high rates leads to 
auricular fibrillation is explained by the acetylcholine so produced. In our previous paper we suggested that production of fibrillation in this way was due to the use of electrodes that produced trauma. We believe that trauma introduces another factor, but we have recently observed the production of flutter persisting for a few minutes after withdrawal of the stimulus when using electrodes that caused minimal trauma. However, such flutter is exceptional and brief; as a rule the acetylcholine formed is destroyed too quickly.

The observations described in this paper represent additional evidence that the beating heart liberates acetylcholine and that the amount liberated is increased when the rate of beating rises. That which is liberated when no stimulation is applied to the vagus nerve or to the heart itself may be certainly described as intrinsic. To judge from the evidence that the activity of the isolated auricles of the rabbit varies with the power of the auricular tissue to synthesize acetylcholine, it would appear that the intrinsic formation is of great importance for the cardiac mechanism, and that this formation may constitute the building up of the excitement which leads to each contraction. Thus it may play a part in cardiac muscle somewhat analogous to the part it plays in skeletal muscle where its arrival at the motor end plate causes a flow of current that leads to a propagated disturbance. Or its role may be to facilitate the development of such a disturbance in response to some other more basic processes.

It is certain that both acetylcholine and cholinesterase inhibitors can exaggerate processes that are part of the normal cardiac function, as is illustrated by the effect of inhibitors of cholinesterase in lowering the rate of stimulation at which A-V block begins. This effect is abolished by atropine, but block still occurs though only at a higher auricular rate. Thus the production of block is possible when the action of acetylcholine is excluded by atropine. However, in the absence of atropine block is greatly facilitated by acetylcholine.

The results obtained in this and the preceding paper (Burn et al., 1955a) are perhaps of clinical interest concerning the cause of auricular fibrillation. We have produced this regularly by stimulating the auricle in the heart-lung preparation either during the infusion of acetylcholine or after the addition of an inhibitor of cholinesterase to the blood. The stimulation necessary during the infusion of acetylcholine was no more than two or three shocks in some experiments, and the results suggested that auricular fibrillation might be expected to arise in man when an ectopic focus began to discharge impulses during a period of continued high vagal tone, or during a period in which much acetylcholine was produced by the heart itself due to a high spontaneous rate.

\section{SUMMARY}

When eserine (physostigmine) or neostigmine (prostigmin) is injected into the normal circulation, the heart rate is slowed. This action is considered equivalent to increased vagal action, since it is explained by a lessened rate of destruction of the acetycholine that is liberated by vagal stimulation. The experiments now described have been carried out in the heart-lung preparation of the dog in which the vagi are cut. When physostigmine or prostigmin was added to the blood it produced effects similar to those produced by acetylcholine, namely, slowing of the heart rate, prolongation of the P-R interval, and reduction of the output; these effects were abolished by atropine. Thus it appeared that in the heart-lung preparation, acetylcholine was being liberated from some point other than the vagal nerve endings.

When the heart was driven electrically by stimulation applied to the right auricle, it was found that when stimulation stopped, the spontaneous rate was less than before the stimulation began; also the P-R interval was prolonged and the output was reduced. In a few minutes the initial values were restored. Thus it appeared that electrical stimulation of the heart caused the appearance of acetycholine in the blood, this acetylcholine being destroyed in a few minutes.

When the heart was driven electrically at increasing rates a critical point was reached at which the ventricular rate fell below the auricular rate (partial block), and at higher rates of stimulation the ventricular fell to half the auricular rate $(2: 1$ block). In the presence of eserine or other inhibitors of cholinesterase the critical rate of stimulation for the commencement of block was much 
lower; the rate at which the $2: 1$ rhythm occurred was also much lower. When atropine was added these changes were reversed.

When the heart was driven electrically at increasing rates in the presence of higher concentrations of eserine or other inhibitors of cholinesterase, auricular fibrillation was produced. When the stimulation was stopped the fibrillation continued for a short time, the length of time being greater according to the concentration of inhibitor that was present. We have shown previously that, when acetylcholine is infused and the heart is stimulated electrically, auricular fibrillation is produced. The present evidence therefore suggests that acetylcholine set free in the heart and preserved by an inhibitor of cholinesterase can also cause auricular fibrillation when the heart is stimulated electrically.

We wish to thank Mr. H. W. Ling for his invaluable help in the experiments. One of us (J.H.B.) is indebted to the Royal Society for a grant to purchase the Cossor electrocardiograph. We also wish to thank Sir Charles Lovatt Evans for a supply of Paraoxon, Dr. D. W. Adamson for a supply of BW.284C.51, and the Hoffmann-la-Roche Co. for a supply of Nu 683.

\section{REFERENCES}

Briscoe, S., and Burn, J. H. (1954). J. Physiol., 126, 181.

Bülbring, E., and Burn, J. H. (1949). J. Physiol., 108, 508.

,-- , and Shelley, H. J. (1953). Proc. Roy. Soc. B., 141, 445.

Burn, J. H., and Walker, J. M. (1954). J. Physiol., 124, 489.

-, Williams, E. M. V., and Walker, J. M. (1955a). J. Physiol. (in the press).

Comline, R. S. (1955b) Brit. med. J., 1, 574.

Cray, J, (1924). (1946). J. Physiol., 105, 6 P

Poc. Roy. Soc. B, 96, 95

Knowlton, F. P., and Starling, E. H. (1912). J. Physiol., 44, 206.

Ord, M. G., and Thompson, R. H. S. (1950). Biochem. J., 46, 346.

Rothberger, J., and Winterberg, H. (1910). Pflüg. Arch. ges. Physiol., 131, 387.

Tedeschi, R. E. (1954). Brit. J. Pharmacol, 9, 367. 